\title{
Biomass and sugar production dynamics in sweet sorghum variety Roger
}

\author{
Iosvany López-Sandin ${ }^{1}$, Guadalupe Gutiérrez-Soto ${ }^{1}$, Adriana Gutiérrez-Díez ${ }^{1}$, Nancy Medina-Herrera ${ }^{1}$, \\ Edgar Gutiérrez-Castorena ${ }^{1}$, Marisol Galicia-Juárez ${ }^{1}$, and Francisco Zavala-García ${ }^{{ }^{*}}$
}

${ }^{1}$ Universidad Autónoma de Nuevo León, Facultad de Agronomía, Francisco Villa S/N Col. Ex Hacienda El Canadá 66415, General Escobedo, N.L., México. "Corresponding author (francisco.zavala.garcia@gmail.com).

Received: 6 July 2020; Accepted: 26 September 2020; doi:10.4067/S0718-58392021000100092

\begin{abstract}
Sweet sorghum (Sorghum bicolor [L.] Moench) is a crop that is well known for its high production of biomass and sugars in the stem juice. The objective of this work was to evaluate the productivity of sweet sorghum 'Roger' based on the dynamics of sugar production and dry biomass by considering different production methods and plant phenological stages. The experimental design consisted of different tillage and fertilization methods established in a randomized complete block design with a split plot arrangement. Tillage treatments were assigned to the plot using the three levels of minimum tillage, traditional tillage, and traditional tillage that included a subsoil operation. Fertilization treatments were assigned to the subplot using the three levels of organic fertilizer, inorganic fertilizer, and without fertilizer. Data collection was performed at different plant phenological stages from anthesis to physiological maturity. Results showed that evaluated agronomic parameters depended on the phenological stage $(\mathrm{P}<0.05)$ rather than the production methods $(\mathrm{P}>0.05)$. Thus, the distribution and accumulation of sugar by stem internodes was associated with plant phenological components. The highest values of the concentration of total soluble solids (14.89\%), juice sugar content (22.91 g), juice sugar concentration $\left(527.46 \mathrm{mg} \mathrm{g}^{-1} \mathrm{DW}\right)$, dry biomass (60.04\%), and dry biomass yield (19.01 $\left.\mathrm{tha}^{-1}\right)$ were observed at the physiological maturity stage of the plant.
\end{abstract}

Key words: Anthesis, fertilizer, phenological stage, Sorghum bicolor, tillage.

\section{INTRODUCTION}

Sweet sorghum (Sorghum bicolor [L.] Moench) is a C4 crop that can be grown in different agroclimatic conditions and production systems with minimum inputs. It is characterized by high biomass production and stem sugar accumulation, highlighting its great bioenergetic potential (Shukla et al., 2017). This crop can be processed as biofuel or valuable coproducts, while not affecting the production of grain as food, fuel, and fodder; it reduces the conflict they generate in food security, as occurs with other crops for bioenergetic purposes, such as sugarcane, sugar beet, corn, and wheat. It also allows multiple cultivation cycles each year, which have high productivity and agronomic stability with minimal demand for N (Rolz et al., 2017).

Sweet sorghum is genetically very diverse, showing a great variation in its agronomic parameters compared with other crops. However, to achieve maximum productivity, appropriate agronomic management is necessary. It has been observed that $\mathrm{N}$ influences biomass production, content and types of sugars in the juice, and soil properties, which can be handled favorably if the right tillage method is selected (Adimassu et al., 2019). The promising potential of sweet sorghum increases its scope of study by emphasizing the use of different fertilizer types and tillage methods. In addition, in the estimation and evaluation of ethanol based on the agronomic traits and juice characteristics of the stems present in progenitors, there are pure lines and varieties that can be used in the biofuel industry (Bunphan et al., 2015). The type of 
applied fertilizer and tillage method can determine crop quality and agricultural yields, High $\mathrm{N}$ and $\mathrm{P}$ fertilization rates can increase production costs and promote environmental pollution. Likewise, the tillage method can increase the degree of soil compaction (Liu et al., 2019; Biberdzic et al., 2020).

The identification of the appropriate harvest stage is decisive for sweet sorghum production for commercial purposes and sustainment of the bioethanol production chain (Kumar et al., 2010). The dynamics of sugar accumulation and biomass production must therefore be considered. It is necessary to point out the study at the internode level to observe the distribution of these sugars along the stem (Tovignan et al., 2016). Therefore, the aim of this research study was to evaluate the productivity of sweet sorghum 'Roger' based on the dynamics of sugar and dry biomass production by considering different production methods and plant phenological stages.

\section{MATERIALS AND METHODS}

The experiment was established in the spring-summer cycle in 2018 at the Marín experimental field of the Facultad de Agronomía belonging to the Universidad Autónoma de Nuevo León (UANL) located in the municipality of Marín $\left(25^{\circ} 52^{\prime} 13.5^{\prime \prime} \mathrm{N}, 100^{\circ} 02^{\prime} 22.56^{\prime \prime} \mathrm{W} ; 355 \mathrm{~m}\right.$ a.s.1.) in the state of Nuevo León, Mexico. The climate is BS1 (h) w (e), described as a warm dry steppe climate with summer rains and $595 \mathrm{~mm}$ mean annual precipitation and $22^{\circ} \mathrm{C}$ temperature. The predominant soil in the area is Vertisol (Soil Survey Staff, 1999) with pH ranging from 7.5 to 8.5 and low organic matter content.

Sweet sorghum (Sorghum bicolor [L.] Moench) 'Roger' is registered by the UANL in the Plant Varieties National Catalog with the SOG-261-050315 name and registration number. This genotype averages $75 \mathrm{~d}$ for flowering and has a 130-d growing cycle.

\section{Establishment and experimental design}

Soil preparation activities to establish the crop began on 20 November 2017 with land clearing tasks. Subsequently, breaking, subsoiling, and harrowing were carried out according to the tillage method. Sowing was on 5 March 2018 at a depth of $0.05 \mathrm{~m}, 0.8 \mathrm{~m}$ row spacing, and $7 \mathrm{~kg} \mathrm{ha}^{-1}$ seeding rate using an experimental seeder (Almaco CTS EO, Specialized Agricultural Equipment, Nevada, Iowa, USA). Manual thinning was performed $20 \mathrm{~d}$ after sowing to obtain a mean density of 18 plants $\mathrm{m}^{-2}$. Fertilization work began $20 \mathrm{~d}$ before sowing by applying Meyfer organic fertilizer (chicken manure as main ingredient; Vertia, Marín, Nuevo León, Mexico) with a $3 \mathrm{t} \mathrm{ha}^{-1}$ manure rate (60 kg N ha-1 $, 65 \mathrm{~kg} \mathrm{Pha}^{-1}, 75$ $\mathrm{kg} \mathrm{K} \mathrm{ha}^{-1}$ ). Ammonium sulphate, as inorganic fertilizer (Fertiquim, Tlajomulco de Zuñiga, Jalisco, Mexico), was spread during sowing $\left(50 \mathrm{~kg} \mathrm{~N}^{-1}, 25 \mathrm{~kg} \mathrm{Pha}^{-1}\right)$ and $25 \mathrm{~d}_{\text {later }}\left(50 \mathrm{~kg} \mathrm{~N} \mathrm{ha}^{-1}, 25 \mathrm{~kg} \mathrm{Pha}^{-1}\right)$. Permethrin insecticide (Pounce 340 CE, FMC Agroquímica de México, S. de R.L. de C.V., Zapopan, Jalisco, Mexico) was applied at $0.6 \mathrm{~L} \mathrm{ha}^{-1}$ on days 28 and 59 after sowing for agricultural pest control. Imidacloprid and betacyflutrin, $0.3 \mathrm{~L} \mathrm{ha}^{-1}$, (Murralla Max $300 \mathrm{OD}$, Bayer, Ecatepec de Morelos, Estado de Mexico, Mexico) were used to control yellow aphid, and they were applied on days 32 and 81 after sowing. For weed control, $1 \mathrm{~L} \mathrm{ha}^{-1}$ 2,4-D dimethylamine salt (Fito Amina 40 herbicide, Dragón, Puebla, Puebla, Mexico) was applied 35 and $64 \mathrm{~d}$ after sowing. A surface drip system was used for irrigation, which was carried out before sowing and five watering events at 14-d intervals.

The agronomic management of the experimental plots was the tillage method (T), fertilizer type (F), internode (IN) position on the stem, and plant phenological stage (PS). Experimental treatments (ET) derived from different Ts and Fs were established as a randomized complete block design with split plot arrangements and three replicates. Each experimental unit was $250 \mathrm{~m}^{2}$. Tillage treatments were assigned to the large plot at the three levels of minimal integrated tillage for clearing and harrowing operations (up to $0.20 \mathrm{~m}$ depth) (T1), traditional integrated tillage for clearing, plowing, and harrowing operations (up to $0.30 \mathrm{~m}$ depth) (T2), and traditional tillage that included a subsoiling operation (up to $0.75 \mathrm{~m}$ depth) (T3). The fertilization treatments were assigned to the subplot at the three levels of organic fertilizer (F1), inorganic fertilizer (F2), and without fertilizer (F3). The tillage and fertilizer combinations generated nine treatments.

\section{Data collection}

Data collection was performed at different PSs as described by Vanderlip (1993). The PS was identified visually (Figure 1). The first sampling (PS6) consisted of 50\% of the plants per treatment at some stage of flowering. The second sampling 
(PS7) occurred when flowering and pollination were complete and grain filling had begun. The third sampling (PS8) was when grains contained hard dough. The fourth sampling (PS9) was when the crop had reached the physiological maturity stage. The presence of the black layer on the hilum at the base of the seed and a black dot in the stylar region were observed once the glume was removed from the grain. In the last sampling, IN measurements were not performed.

\section{Agronomic parameters for each internode}

Data collection for INs in the corresponding PS was carried out by selecting 10 plants with complete competition in each plot. Leaves and leaf sheaths were removed from each plant, leaving only the stem (bare stem). The stem was cut into pieces according to the nodes present at the time of sampling. The IN measurement was performed by numbering the internodes from the top to the base of the stem. Internode length (IL) and diameter (ID) were determined for each IN. The INs were immediately cut in half to extract a juice sample that was deposited in a digital refractometer (PAL-1, ATAGO USA, Bellevue, Washington, USA) to measure the concentration of total soluble solids (TSS).

\section{Biomass}

To estimate biomass, the plant was separated into morphological components (leaves, stem, and panicle), which were placed separately in paper bags and weighed on an analytical scale (L-EQ, Torrey, Ciudad de México, Mexico) to obtain fresh weight. The bags were placed in an oven (HAFO 1600 series, Cornelius, Oregon, USA) at $65^{\circ} \mathrm{C}$ until reaching constant weight to determine the dry weight (DW) of each component, plant dry weight (PDW), and dry biomass yield per hectare (DBY). The percentage of dry biomass (DB) was determined by Equation 1 as:

$$
D B_{M C}(\%)=\frac{D W_{M C}(g)}{P D W_{M C}(g)} \times 100
$$

where MC is the morphological component, DW is dry weight, and PDW is plant dry weight.

\section{Production of stem sugar and juice dynamics}

Juice was obtained by another sample of 10 stems per plot taken at each PS and processed in a juice extractor (QJH-L100 A, Kuala Lumpur, Malaysia). The juice was filtered through a sieve to remove residues and obtain juice weight (JW) and TSS concentration. Juice extraction capacity (JEC), juice sugar content (JSC), and juice sugar concentration (JSCN) were also determined by Equations 2, 3, and 4 (Tovignan et al., 2016; Rono et al., 2018):

$$
J E C(\%)=\frac{J W(g)}{S F W(g)} \times 100
$$

where JW is juice weight and SFW is stem fresh weight.

$$
J S C(g)=\frac{T S S \times 8.827 \times[S F W(g)-S D W(g)]}{1000}
$$

where 8.827 is the slope of the regression line between TSS and sugar concentration $\left(\mathrm{g} \mathrm{L}^{-1}\right)$ and SDW is stem dry weight.

$$
J S C N\left(\mathrm{mg} g^{-1} \mathrm{DW}\right)=\frac{J S C(g)}{S D W(g)} \times 1000
$$

Figure 1. Phenological stages (PS) evaluated in sweet sorghum 'Roger': Anthesis (PS6), grain filling (PS7), hard dough grains (PS8), and physiological maturity (PS9).

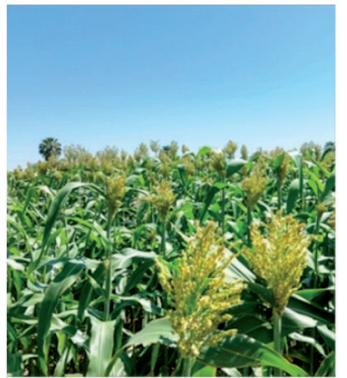

PS6

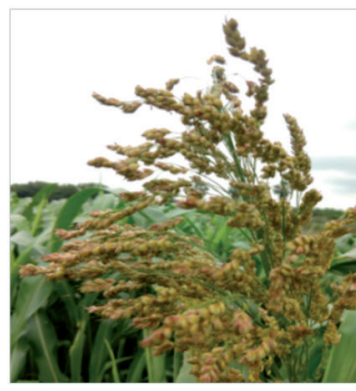

PS7

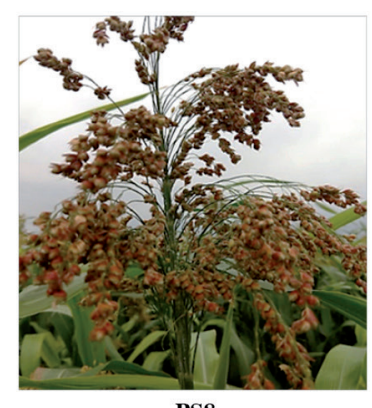

PS8

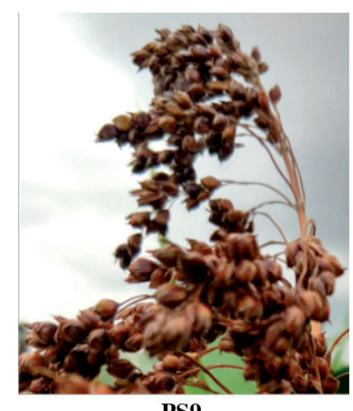

PS9 


\section{Statistical analysis}

The data generated by the effect of different sources of variation on the study variables were statistically contrasted by ANOVA and a comparison of means according to Fisher's LSD test at a significance level of 95\% ( $\mathrm{P} \leq 0.05)$. In addition, a correlation analysis was performed using Pearson's coefficient. An angular transformation [arccosine (Yi) 1/2] was performed on the percentage data (Yi), which were transformed to the original scale (\%) after being statistically processed. The analyses were performed with the InfoStat statistical software (Universidad Nacional de Córdoba, Córdoba, Argentina).

\section{RESULTS AND DISCUSSION}

The combined ANOVA for the agronomic traits studied for INs is shown in Table 1. A significant difference $(\mathrm{P}<0.01)$ was observed for PS only in TSS and INs for all studied traits. Regarding interactions, a significant difference $(\mathrm{P}<0.01)$ was observed in the IN $\times$ PS interaction for TSS and IL.

\section{Sugar distribution and accumulation in the internodes}

Given that the stem of sweet sorghum is considered as a sink tissue for non-structural carbohydrates (Bihmidine et al., 2015) and that plant PS influences the distribution and accumulation of sugar in the INs of 'Roger' (Table 1), we proceeded to identify its dynamics (Figure 2). The highest concentration of TSS during PS6 was observed for IN1 to IN4 (Figure 2a). The highest values for PS7 occurred for IN2 to IN6 (Figure 2b). Once PS8 was reached, the highest values were observed for IN4 and IN5 (Figure 2c), indicating that sugar content in the higher INs decreases with plant maturity after anthesis, as opposed to the upper intermediate INs. This was detected in more detail in the individual analysis of each IN (Figure 2d). Both IN1 (11.59\%) and IN2 (11.43\%) had the same behavior $(\mathrm{P}>0.05)$ in all the PSs. Both INs showed the highest TSS value in PS6, which decreased significantly in PS7 and had a slight decrease in PS8. This behavior could be associated with the fact that the panicle does not initially exert a significant demand for carbohydrates being generated by photosynthesis in the upper part of the stem, and resulting in a greater accumulation of sugars in the upper part (Bihmidine et al., 2015). There are reports that sugar accumulation can occur mainly before anthesis once the first INs complete elongation, increasing when leaf and stem growth stops at anthesis, thus avoiding competition with grain filling (Gutjahr et al., 2013).

Table 1. Mean squares of ANOVA of agronomic parameters for each internode at the plant phenological stages and for production methods.

\begin{tabular}{|c|c|c|c|c|}
\hline & $\begin{array}{l}\text { Degrees of } \\
\text { freedom }\end{array}$ & $\begin{array}{l}\text { Concentration of } \\
\text { total soluble solids }\end{array}$ & $\begin{array}{l}\text { Internode } \\
\text { length }\end{array}$ & $\begin{array}{l}\text { Internode } \\
\text { diameter }\end{array}$ \\
\hline PS & 2 & $127.89 * *$ & $9.44 \mathrm{~ns}$ & $0.21 \mathrm{~ns}$ \\
\hline $\mathrm{PS}>\mathrm{R}$ & 6 & $51.04 \mathrm{~ns}$ & $48.66 n s$ & $2.55 \mathrm{~ns}$ \\
\hline $\mathrm{T}$ & 2 & $45.68 \mathrm{~ns}$ & $23.11 \mathrm{~ns}$ & $0.05 \mathrm{~ns}$ \\
\hline $\mathrm{PS} \times \mathrm{T}$ & 4 & $9.43 \mathrm{~ns}$ & $2.42 \mathrm{~ns}$ & $0.36 \mathrm{~ns}$ \\
\hline $\mathrm{PS}>\mathrm{R} \times \mathrm{T}$ & 12 & 20.43 & 11.47 & 0.42 \\
\hline $\mathrm{F}$ & 2 & $7.37 \mathrm{~ns}$ & $13.36 \mathrm{~ns}$ & $0.12 \mathrm{~ns}$ \\
\hline $\mathrm{F} \times \mathrm{PS}$ & 4 & $11.62 \mathrm{~ns}$ & $0.75 \mathrm{~ns}$ & $0.32 \mathrm{~ns}$ \\
\hline $\mathrm{F} \times \mathrm{T}$ & 4 & $6.42 \mathrm{~ns}$ & $10.23 \mathrm{~ns}$ & $1.44 \mathrm{~ns}$ \\
\hline $\mathrm{F} \times \mathrm{PS} \times \mathrm{T}$ & 8 & $11.54 \mathrm{~ns}$ & $13.58 \mathrm{~ns}$ & $0.98 \mathrm{~ns}$ \\
\hline $\mathrm{PS}>\mathrm{T}>\mathrm{R} \times \mathrm{F}$ & 36 & 15.6 & 10.72 & 0.92 \\
\hline IN & 9 & $244.78 * *$ & $3990.09 * *$ & $5.39 * *$ \\
\hline $\mathrm{IN} \times \mathrm{PS}$ & 18 & $16.72 * *$ & $30.79 * *$ & $0.05 \mathrm{~ns}$ \\
\hline $\mathrm{IN} \times \mathrm{T}$ & 18 & $3.25 \mathrm{~ns}$ & $10.22 \mathrm{~ns}$ & $0.02 \mathrm{~ns}$ \\
\hline $\mathrm{IN} \times \mathrm{F}$ & 18 & $1.63 \mathrm{~ns}$ & $5.76 \mathrm{~ns}$ & $0.02 \mathrm{~ns}$ \\
\hline $\mathrm{IN} \times \mathrm{PS} \times \mathrm{T}$ & 36 & $1.25 \mathrm{~ns}$ & $6.56 \mathrm{~ns}$ & $0.02 \mathrm{~ns}$ \\
\hline $\mathrm{IN} \times \mathrm{PS} \times \mathrm{F}$ & 36 & $1.86 \mathrm{~ns}$ & $4.15 \mathrm{~ns}$ & $0.02 \mathrm{~ns}$ \\
\hline $\mathrm{IN} \times \mathrm{T} \times \mathrm{F}$ & 36 & $1.71 \mathrm{~ns}$ & $5.55 \mathrm{~ns}$ & $0.05 \mathrm{~ns}$ \\
\hline Error & 558 & 1.76 & 10.74 & 0.03 \\
\hline $\mathrm{CV}, \%$ & & 13.77 & 15.16 & 14.62 \\
\hline
\end{tabular}

*, ** Significant at $\mathrm{P}<0.05$ and $\mathrm{P}<0.01$, respectively; ns: nonsignificant.

PS: Phenological stage; R: replicate; T: tillage method; F: fertilizer type; IN: internode. 
Figure 2. Evolution of the concentration of total soluble solids (TSS) by internodes in the phenological stages (PS) of the plant.
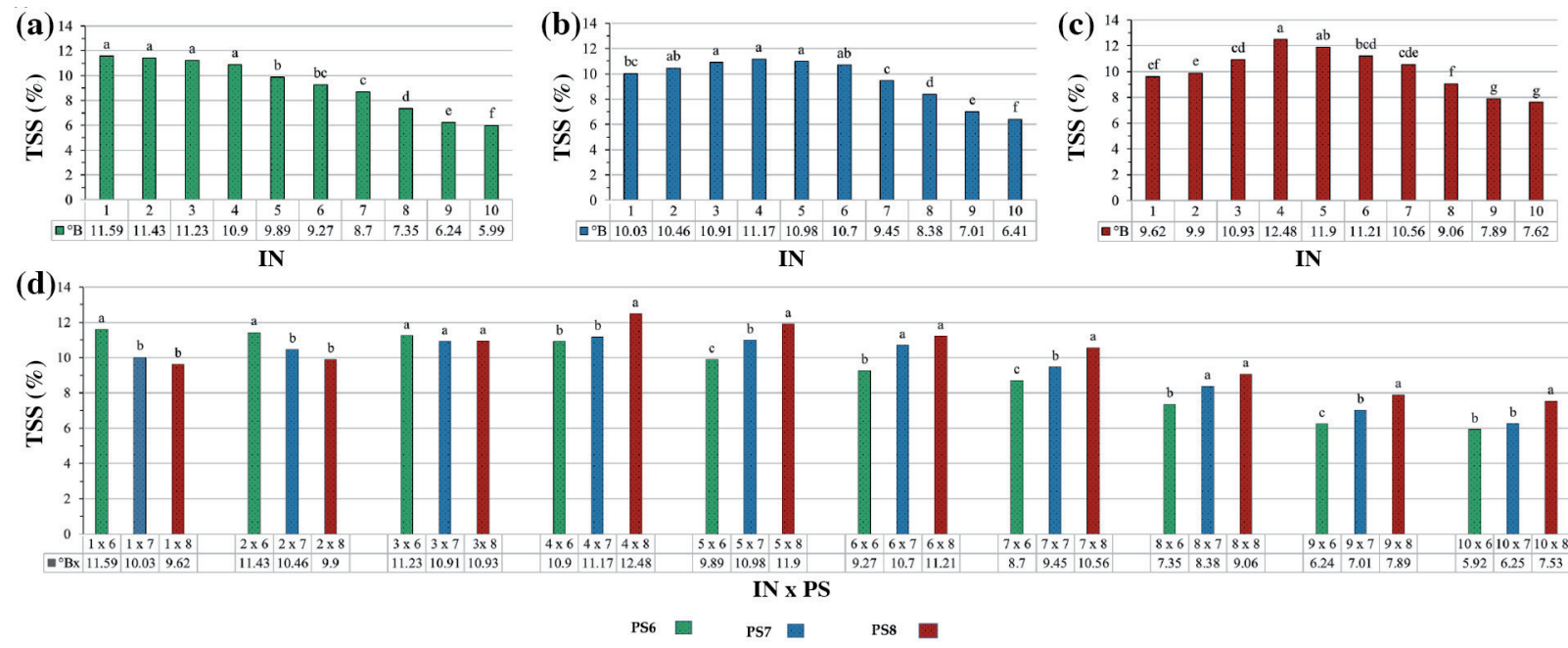

Different letters over the bars indicate significant differences according to Fisher's LSD test $(\mathrm{P}<0.05)$

Distribution between internodes (IN) at anthesis (a), grain filling (b), hard dough grains (c), and accumulation by IN in each PS (d).

However, this behavior changes as the demand for carbohydrates by the developing grain increases over time. The IN3 was the only one that showed no difference $(\mathrm{P}>0.05)$ throughout the PSs. The rest of the INs toward the base of the stem (IN4 to IN10) increased their values with plant maturity. Specifically, IN5, IN7, and IN9 were the only ones that showed a difference $(\mathrm{P}<0.05)$ in all the PSs, and this could be a variety characteristic. The highest TSS value usually occurred in IN4 and IN5 (upper intermediates) when the plant reached a certain degree of maturity (PS8), while the lowest value was found in the INs at the base of the stem, resulting in behavior that was similar to other studies (Morey et al., 2018). Therefore, sugar accumulation by INs depends, among other factors, on its position on the stem, on the number of INs and their dimensions, on the PS, and variety of sweet sorghum (Morey et al., 2018). In some sorghum varieties, the accumulation of sugar is more associated with the age of the INs than with the phenology of the plant itself. The latter is influenced by the effects of the photoperiod, which varies among varieties and site-specific conditions (Gutjahr et al., 2013). A positive correlation ( $P<0.01)$ was observed for TSS and IL. On the contrary, both parameters were negatively related $(\mathrm{P}<0.01)$ with diameter (Table 2$)$. This suggests that sugar distribution and accumulation in the INs usually depend on plant phenological factors.

\section{Internode length and diameter}

The greatest length of IN1 $(39.41 \mathrm{~cm}$ ) was observed in PS8 (Figure 3), and it was double the length of the other INs. This internode is unique because it corresponds to the peduncle of the panicle and is not a typical internode of the main stem. Most of the INs showed no difference (P > 0.05) among PSs for this characteristic, except IN1, IN5, IN6, and IN10. The mean IN length was $21.61 \mathrm{~cm}$. Some of these traits were similar to other varieties that reported the IN farthest from the base of the stem as the longest, averaging $40 \mathrm{~cm}$, and with a mean of $22 \mathrm{~cm}$ for the rest of the INs (Bihmidine et al., 2015; Tovignan et al., 2016). These results could be associated with the development of the plant's vascular system, which allows its growth throughout the life cycle by forming new tissues and organs resulting from cell division (Miyashima et al., 2013). It is known

Table 2. Pearson's correlation for the agronomic parameters measured for each internode.

\begin{tabular}{lccc}
\hline & $\begin{array}{c}\text { Concentration of } \\
\text { total soluble solids }\end{array}$ & $\begin{array}{c}\text { Internode } \\
\text { length }\end{array}$ & $\begin{array}{c}\text { Internode } \\
\text { diameter }\end{array}$ \\
\hline $\begin{array}{l}\text { Concentration of total soluble solids } \\
\text { Internode length }\end{array}$ & 1 & & \\
Internode diameter & $0.249^{* *}$ & 1 & 1 \\
\hline
\end{tabular}

** Significant at $\mathrm{P}<0.01$. 
Figure 3. Internode length (IL) evolution for each plant phenological stage (PS).

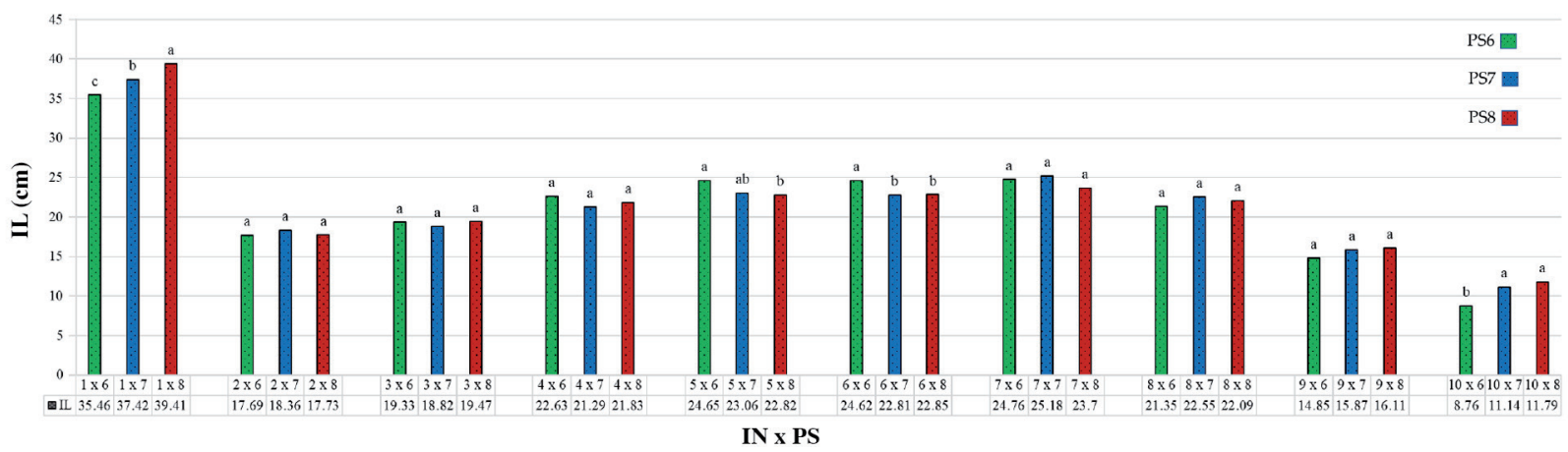

Different letters over bars indicate significant differences according to Fisher's LSD test $(\mathrm{P}<0.05)$. PS6: Anthesis; PS7: grain filling; PS8: hard dough grains.

that IN dimensions can vary due to the effect of humidity, temperature, photoperiod, planting season, and planting density (Tsuchihashi and Goto, 2005). The latter can increase plant height as a result of competition for light, water, and nutrients, mainly inducing an increase in the number of INs or their dimensions (Ayub et al., 2002; Tang et al., 2018). This indicates that the production conditions influence the stem characteristics of each variety.

For IN diameter, there was nonsignificant difference $(\mathrm{P}>0.05)$ between the PS or production system (Table 1). However, the distribution along the stem followed a certain behavior pattern for this variable $(\mathrm{P}<0.01)$. Figure 4 shows that IN8, IN9, and IN10 (those closest to the stem base) have a larger diameter $(1.53,1.52$, and $1.49 \mathrm{~cm}$, respectively), which decreases as they approach the stem apex, and IN1 $(0.79 \mathrm{~cm})$ is the thinnest. These morphological features have been reported in other sorghum genotypes and are mainly associated with the stem biomechanical function of each variety. This depends on genetics and its effects on stem morphological characteristics (Gomez et al., 2017), mostly conditioned by environmental and production factors (Tsuchihashi and Goto, 2005). Likewise, the number of INs depends on the variety, water availability, harvest stage, and planting time (Tsuchihashi and Goto, 2005; Morey et al., 2018). It should be mentioned that the values for 'Roger' were in the range reported for other varieties from 0.7 to $3.13 \mathrm{~cm}$ (Mangena et al., 2018).

\section{Biomass}

Table 3 shows ANOVA for biomass, juice, and sugar production. Biomass production showed a significant difference (P $<0.05$ ) only for the effect of PS and no interaction with the other factors.

Means in Table 4 exhibit the highest DBY in PS7 (from 18.65 to $19.01 \mathrm{tha}^{-1}$ ) ranging from 14.8 to $35.2 \mathrm{t} \mathrm{ha}^{-1}$ as in other sweet sorghum varieties (Zhao et al., 2009). The highest contribution to DBY was made by the stem and the highest value was in PS9 (60.04\%); this behavior was similar to that of other varieties (Zhao et al., 2009). However, this was less than

Figure 4. Internode diameter (ID) behavior related to the internode (IN) position on the plant stem.

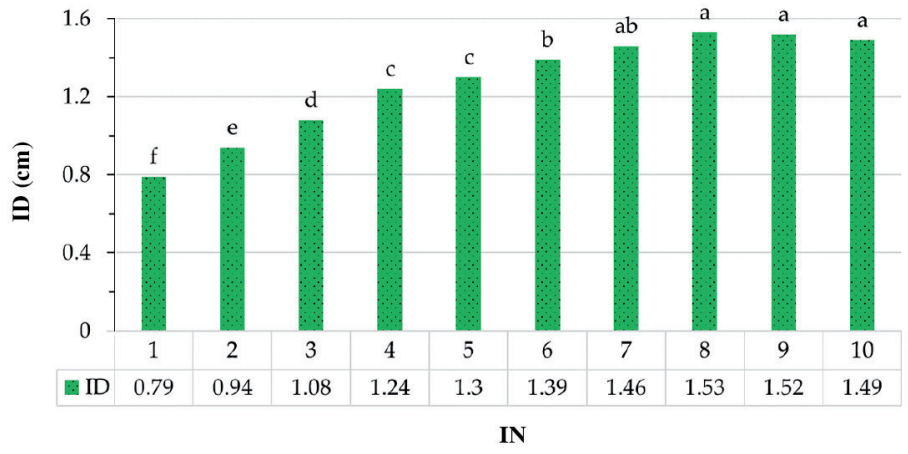

Different letters over the bars indicate significant differences according to Fisher's LSD test $(\mathrm{P}<0.05)$.

1-10: Internode number from the upper part (1) to the base (10) of the stem. 
the range from 63.4\% to 76.6\% reported by Pannacci and Bartolini (2016), and this could be related to a lower planting density in 'Roger'. Biomass production can also vary among sweet sorghum varieties and depend, among other factors, on the time of harvest, plant height, soil moisture, tillage method, and applied fertilizer type (Pittelkow et al., 2015; Zhang et al., 2016; Olugbemi et al., 2018).

Fertilization, mainly N, can increase biomass production, especially chemical fertilizers that have become more efficient than organic ones. Although the latter have a positive impact on soil properties, they improve biomass yield in subsequent crop cycles (Ayub et al., 2002; Pannacci and Bartolini, 2016). Similarly, climatic conditions and planting date

Table 3. Mean squares of the ANOVA for the production of dry biomass, juice, and stem sugar at the plant phenological stages and for production methods.

\begin{tabular}{|c|c|c|c|c|c|c|c|c|c|c|}
\hline \multirow[b]{2}{*}{ SV } & \multirow[b]{2}{*}{ DF } & \multicolumn{9}{|c|}{ MS } \\
\hline & & LDB & SDB & PDB & DBY & JW & TSS & JEC & JSC & JSCN \\
\hline PS & 3 & $371.86^{* *}$ & $375.42 * *$ & $538.34 * *$ & $613.78 * *$ & $1168.52 *$ & $134.27 * *$ & $16.81^{*}$ & $373.35 * *$ & $252245.57 * *$ \\
\hline $\mathrm{PS}>\mathrm{R}$ & 8 & 26.42 & 81.21 & 66.39 & 11.77 & 342.41 & 10.02 & 1.96 & 48.48 & 11114.18 \\
\hline $\mathrm{T}$ & 2 & $0.10 \mathrm{~ns}$ & $10.90 \mathrm{~ns}$ & $15.48 \mathrm{~ns}$ & $13.54 \mathrm{~ns}$ & $118.59 \mathrm{~ns}$ & $4.14 \mathrm{~ns}$ & $6.58 \mathrm{~ns}$ & $12.59 \mathrm{~ns}$ & $17099.14 \mathrm{~ns}$ \\
\hline $\mathrm{T} \times \mathrm{PS}$ & 6 & $13.86 \mathrm{~ns}$ & $18.97 \mathrm{~ns}$ & $18.68 \mathrm{~ns}$ & $50.76 \mathrm{~ns}$ & $1336.27 * *$ & $2.80 \mathrm{~ns}$ & $8.99^{*}$ & $38.77 *$ & $21621.37 *$ \\
\hline $\mathrm{PS}>\mathrm{T} \times \mathrm{R}$ & 16 & 8.92 & 17.74 & 23.86 & 24.03 & 250.68 & 1.63 & 2.74 & 6.36 & 6820.18 \\
\hline $\mathrm{F}$ & 2 & $9.85 \mathrm{~ns}$ & $2.99 \mathrm{~ns}$ & $3.16 \mathrm{~ns}$ & $36.02 \mathrm{~ns}$ & 204.79ns & $0.11 \mathrm{~ns}$ & $2.94 \mathrm{~ns}$ & $0.89 \mathrm{~ns}$ & $15910.92 \mathrm{~ns}$ \\
\hline $\mathrm{F} \times \mathrm{PS}$ & 6 & $3.95 \mathrm{~ns}$ & $8.78 \mathrm{~ns}$ & $3.96 \mathrm{~ns}$ & $44.90 \mathrm{~ns}$ & $181.36 \mathrm{~ns}$ & $1.50 \mathrm{~ns}$ & $0.89 \mathrm{~ns}$ & $10.80 \mathrm{~ns}$ & $5863.27 \mathrm{~ns}$ \\
\hline $\mathrm{F} \times \mathrm{T}$ & 4 & $4.06 \mathrm{~ns}$ & $14.69 \mathrm{~ns}$ & $7.74 \mathrm{~ns}$ & $71.57 \mathrm{~ns}$ & $208.50 \mathrm{~ns}$ & $1.07 \mathrm{~ns}$ & $1.17 \mathrm{~ns}$ & $6.68 \mathrm{~ns}$ & $5649.03 \mathrm{~ns}$ \\
\hline $\mathrm{F} \times \mathrm{PS} \times \mathrm{T}$ & 12 & $3.76 \mathrm{~ns}$ & $12.63 \mathrm{~ns}$ & $10.63 \mathrm{~ns}$ & $41.18 \mathrm{~ns}$ & $135.73 \mathrm{~ns}$ & $0.78 \mathrm{~ns}$ & $0.73 \mathrm{~ns}$ & $3.43 \mathrm{~ns}$ & 4043.86ns \\
\hline Error & 48 & 7.38 & 7.93 & 10.63 & 17.95 & 337.83 & 1.32 & 1.13 & 12.30 & 8422.60 \\
\hline $\mathrm{CV}$ & & 9.70 & 5.96 & 8.16 & 17.37 & 16.70 & 5.94 & 2.57 & 20.01 & 23.28 \\
\hline
\end{tabular}

* ** Significant at $\mathrm{P}<0.05$ and $\mathrm{P}<0.01$, respectively; ns: nonsignificant.

SV: Source of variation; DF: degrees of freedom; MS: mean squares; LDB: dry leaf biomass; SDB: dry stem biomass; PDB: panicle dry biomass; DBY: dry biomass yield; TSS: concentration of total soluble solids; JW: juice weight; JEC: juice extraction capacity; JSC: juice sugar content; JSCN: juice sugar concentration; PS: phenological stage; R: replicate; T: tillage method; F: fertilizer type; CV: coefficient of variation.

Table 4. Comparison of means for dry biomass, juice, and stem sugar production at plant phenological stages and for production methods.

\begin{tabular}{|c|c|c|c|c|c|c|c|c|c|}
\hline \multirow[b]{2}{*}{ SV } & \multicolumn{3}{|c|}{$\mathrm{BS}$} & \multirow[b]{2}{*}{ DBY } & \multirow[b]{2}{*}{ JW } & \multirow[b]{2}{*}{ TSS } & \multirow[b]{2}{*}{ JEC } & \multirow[b]{2}{*}{ JSC } & \multirow[b]{2}{*}{ JSCN } \\
\hline & Leaf & Stem & Panicle & & & & & & \\
\hline & & $-\%$ & 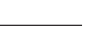 & $\mathrm{tha}^{-1}$ & $\mathrm{~g}_{\text {plant }}{ }^{-1}$ & 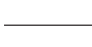 & $6-$ & $\mathrm{g}$ & $\mathrm{mg} \mathrm{g}^{-1} \mathrm{DW}$ \\
\hline \multicolumn{10}{|l|}{ PS } \\
\hline 6 & $34.58 \mathrm{a}$ & $47.44 \mathrm{c}$ & $17.98 b$ & $16.20 \mathrm{~b}$ & $108.80 \mathrm{~b}$ & $9.57 b$ & $42.21 b$ & $15.99 b$ & $313.87 \mathrm{c}$ \\
\hline 7 & $22.44 b$ & $52.67 \mathrm{~b}$ & $24.89 \mathrm{a}$ & $18.65 a$ & $119.48 \mathrm{a}$ & $9.93 b$ & $44.95 \mathrm{a}$ & $16.77 b$ & $402.35 b$ \\
\hline 8 & $23.18 \mathrm{ab}$ & $53.44 \mathrm{ab}$ & $23.38 \mathrm{a}$ & $18.95 \mathrm{a}$ & $107.81 b$ & $10.05 b$ & $42.84 b$ & $14.44 \mathrm{~b}$ & $332.97 \mathrm{bc}$ \\
\hline 9 & $15.16 \mathrm{c}$ & $60.04 \mathrm{a}$ & $24.83 \mathrm{a}$ & $19.01 \mathrm{a}$ & $104.19 b$ & $14.89 \mathrm{a}$ & $44.72 \mathrm{a}$ & $22.91 \mathrm{a}$ & $527.46 a$ \\
\hline Mean & 23.84 & 53.39 & 22.77 & 18.20 & 110.07 & 11.13 & 43.68 & 17.53 & 394.16 \\
\hline $\operatorname{SMD}(0.05)$ & 3.47 & 5.64 & 5.81 & 0.99 & 11.48 & 1.15 & 1.52 & 2.65 & 65.33 \\
\hline \multicolumn{10}{|l|}{$\mathrm{PS} \times \mathrm{T}$} \\
\hline $1 \times 1$ & 28.44 & 48.22 & 23.34 & 15.62 & $112.87 \mathrm{bcd}$ & 17.80 & 41.08bcde & $16.03 \mathrm{de}$ & $336.57 \mathrm{ef}$ \\
\hline $1 \times 2$ & 29.01 & 50.30 & 20.69 & 17.04 & $102.34 \mathrm{cdef}$ & 18.48 & 39.86de & $16.43 d$ & $309.40 \mathrm{ef}$ \\
\hline $1 \times 3$ & 31.24 & 49.49 & 19.17 & 16.36 & 111.19bcde & 17.44 & $40.6 \mathrm{cde}$ & $15.52 \mathrm{def}$ & $295.62 f$ \\
\hline $2 \times 1$ & 27.36 & 47.39 & 25.25 & 20.20 & $113.48 \mathrm{bcd}$ & 17.79 & $41.76 a b c$ & $15.81 \mathrm{def}$ & 378.39de \\
\hline $2 \times 2$ & 29.66 & 44.08 & 26.26 & 17.64 & $112.53 \mathrm{bcd}$ & 17.88 & $41.42 \mathrm{bcd}$ & $17.22 \mathrm{~cd}$ & 391.87de \\
\hline $2 \times 3$ & 28.47 & 48.18 & 23.35 & 18.58 & $132.42 \mathrm{a}$ & 18.86 & $43.11 \mathrm{a}$ & $17.28 \mathrm{~cd}$ & $436.79 \mathrm{bcd}$ \\
\hline $3 \times 1$ & 30.51 & 42.02 & 27.47 & 19.16 & $94.11 \mathrm{f}$ & 18.44 & $39.63 \mathrm{e}$ & $13.44 f$ & $277.60 f$ \\
\hline $3 \times 2$ & 28.96 & 42.79 & 28.25 & 19.12 & 98.64def & 18.83 & $40.46 \mathrm{cde}$ & 13.74ef & $292.82 f$ \\
\hline $3 \times 3$ & 28.83 & 42.17 & 29.00 & 19.06 & $119.80 \mathrm{ab}$ & 18.86 & $42.54 \mathrm{ab}$ & 16.13de & $428.47 \mathrm{~cd}$ \\
\hline $4 \times 1$ & 26.45 & 49.37 & 24.18 & 19.23 & $95.58 \mathrm{ef}$ & 21.95 & $41.84 \mathrm{abc}$ & $19.11 \mathrm{c}$ & $479.45 b c$ \\
\hline $4 \times 2$ & 26.55 & 51.51 & 21.94 & 19.35 & $113.21 \mathrm{bcd}$ & 22.47 & 41.49abcd & $23.19 b$ & $514.96 \mathrm{ab}$ \\
\hline $4 \times 3$ & 27.04 & 51.53 & 21.43 & 20.02 & $114.65 b c$ & 23.60 & $42.57 \mathrm{ab}$ & $26.44 \mathrm{a}$ & $587.97 \mathrm{a}$ \\
\hline Mean & 29.04 & 47.25 & 23.71 & 18.44 & 110.09 & 19.37 & 41.36 & 17.53 & 394.15 \\
\hline $\operatorname{SMD}(0.05)$ & 2.98 & 4.21 & 4.88 & 4.72 & 15.82 & 1.28 & 1.65 & 2.52 & 82.53 \\
\hline
\end{tabular}

Different letters in the same column indicate significant differences according to Fisher's LSD test $(\mathrm{P}<0.05)$.

SV: Source of variation; BS: dry biomass; DBY: dry biomass yield; TSS: concentration total soluble solids; JW: juice weight; JEC: juice extraction capacity; JSC: juice sugar content; JSCN: juice sugar concentration. PS: phenological stage; T: tillage method; SMD: significant minimal difference. 
of sorghum can influence the response efficiency of the crop to fertilization (Maw et al., 2016; Tovignan et al., 2016). The shape and number of leaves in DM production are also important because they determine the efficiency of capturing solar radiation and provide uniform plant development. Thus, the size of the leaf area between floral differentiation and anthesis can influence biomass production (Vermerris and Saballos, 2013; Tang et al., 2018).

\section{Juice and sugar production dynamics}

Based on the accumulation dynamics exhibited by the juice and sugar production of the stem, these components showed a significant difference $(\mathrm{P}<0.01 ; \mathrm{P}<0.05)$ among PSs and in the PS $\times \mathrm{T}$ interaction (Table 3$)$. The PS7 and PS $2 \times \mathrm{T} 3$ interaction had the highest JW values of 119.48 and $132.42 \mathrm{~g} \mathrm{plant}^{-1}$, respectively (Table 4). This indicates a relationship between phenology and tillage method in the juice content of the stem. The present study reported that JW increases after anthesis and at the beginning of the grain filling period. Meanwhile, for the period between the dough stage and physiological maturity, there is a gradual decrease that corresponds to an opposite behavior to that observed in hybrids and improved varieties that showed higher JW at the maturity stage (Kumar et al., 2010). This suggests that JW depends on the phenological characteristics of each variety and its response to the established production conditions (Bihmidine et al., 2015, da Silva et al., 2019).

Therefore, 'Roger' exceeded the reported values of 22.43 and $23 \mathrm{~g} \mathrm{plant}^{-1}$ in two varieties grown under different $\mathrm{N}$ rates, also exceeding the maximum mean value of 54.73 g plant $^{-1}$ reported in 16 genotypes grown in clay-alkaline soil with traditional tillage (Mekdad and Emam, 2019; Bakhite et al., 2019). These last reports were developed under conditions similar to those used in the present study under the traditional tillage method, except for the subsoiling operation, which suggests that deep tillage contributes to increasing juice yield. It is known that using the subsoil plow breaks the plow floor formed by the continuous passing of the machinery over the soil (Zhai et al., 2017), and it favors the penetration and exploration of the roots in the soil, seeking greater water and nutrient availability, increasing the possibilities of the plant adaptating to different soil types and conditions (Schneider et al., 2017; Fan et al., 2017). The JW was positively correlated $(\mathrm{P}<0.01)$ with JEC (Table 5), indicating that JW was associated with JEC. The highest JEC value was observed in PS7 (44.95\%) and in the PS2 $\times$ T3 interaction (43.11\%), although PS7 was equal (P >0.05) to PS9 (44.72\%) (Table 4). This suggests that JEC, as JW, depends on the crop production conditions; and the stem characteristics, mainly the juice content (Tsuchihashi and Goto, 2005). However, Rono et al. (2018) reported values for JEC ranging from 39.8\% to $45.7 \%$, and these exceed the values of $39.02 \%$ and $39.20 \%$ mentioned by Mekdad and Emam (2019).

Regarding sugar production, TSS increased as the PSs advanced (Table 4). They reached the highest value in PS9 (14.89\%), similar to that observed in other varieties (Oyier et al., 2017). A wide range from 3.3\% to 18.9\% has been reported for this characteristic, which depends on the variety and PS (Kumar et al., 2010; Bihmidine et al., 2015; Cole et al., 2017). The TSS were positively correlated $(\mathrm{P}<0.01)$ with SDB, PDB, JSC, and JSCN (Table 5). Both JSC and JSCN showed the highest values in PS9 with $22.91 \mathrm{~g}$ and $527.46 \mathrm{mg} \mathrm{g}^{-1} \mathrm{DW}$, respectively. Both JSC and JSCN showed variation $(\mathrm{P}<0.01)$ in the PS $\times \mathrm{T}$ interaction. Meanwhile, the PS4 $\times$ T3 interaction had the highest values with $26.44 \mathrm{~g}$ and 587.97 $\mathrm{mg} \mathrm{g}^{-1} \mathrm{DW}$, respectively. Both parameters had a positive correlation $(\mathrm{P}<0.01)$, as did JW and SDB (Table 5). This concurs with other studies that have considered the juiciness of the stem as necessary for sugar accumulation, showing variations associated with the proportion of plant biomass (Tovignan et al., 2016; Morey et al., 2018). The results of the present work

Table 5. Pearson's correlation for dry biomass, juice, and sugar production.

\begin{tabular}{llllllll}
\hline & \multicolumn{1}{c}{ LDB } & \multicolumn{1}{c}{ SDB } & PDB & JW & TSS & JEC & JSC \\
\hline LDB & 1 & & & & & & \\
SDB & $-0.492^{* *}$ & 1 & & & & & \\
PDB & $-0.234^{*}$ & $-0.732^{* *}$ & 1 & & & & \\
JW & -0.019 & 0.145 & -0.147 & 1 & & & \\
TSS & $-0.652^{* *}$ & $0.279^{* *}$ & $0.199^{*}$ & -0.05 & 1 & & \\
JEC & $-0.299^{* *}$ & $0.192^{*}$ & 0.02 & $0.714^{* *}$ & 0.09 & 1 & \\
JSC & $-0.492^{* *}$ & $0.356^{* *}$ & -0.012 & $0.479^{* *}$ & $0.817 * *$ & $0.342^{* *}$ & 1 \\
JSCN & $-0.569^{* *}$ & $0.296^{* *}$ & 0.115 & $0.465^{* *}$ & $0.656^{* *}$ & $0.738^{* *}$ & $0.742^{* *}$ \\
\hline
\end{tabular}

*,**Significant at $\mathrm{P}<0.05$ and $\mathrm{P}<0.01$, respectively.

LDB: Leaf dry biomass; SDB: stem dry biomass; PDB: panicle dry biomass; JW: juice weight; TSS: concentration total soluble solids; JEC: juice extraction capacity; JSC: juice sugar content; JSCN: juice sugar concentration. 
for JSC were lower than the range from 27 to $61 \mathrm{~g}$ reported for native African varieties. Meanwhile, JSCN ranged from 482 to $589 \mathrm{mg} \mathrm{g}^{-1}$ DW for these same varieties (Tovignan et al., 2016). The TSS, JSC, and JSCN can significantly increase from anthesis to plant physiological maturity, reaching considerably higher values than grain sorghum (Bihmidine et al., 2015). Therefore, the degree of plant maturity and production conditions are decisive for sugar accumulation in the stem. Some authors mention that the sowing date also influences sugar accumulation in the sweet sorghum stem (Tsuchihashi and Goto, 2005; Tovignan et al., 2016); this also occurs with variations in humidity, temperature, soil fertility, and the quality of irrigation water (Tovignan et al., 2016; Rolz et al., 2017).

\section{CONCLUSIONS}

The distribution and accumulation of sugar by internodes of the stem was associated with plant phenological components (internode length and diameter). However, sugar accumulation and plant biomass increased with physiological maturity. Therefore, the highest concentration values of total soluble solids (14.89\%), juice sugar content (22.91 g), juice sugar concentration (527.46 mg g-1 DW), percentage of dry biomass (60.04\%), and dry biomass yield (19.01 $\left.\mathrm{t} \mathrm{ha}^{-1}\right)$ were observed at the physiological maturity stage of the plant.

\section{ACKNOWLEDGEMENTS}

We thank the Autonomous University of Nuevo León for the support for this research and to the National Council of Science and Technology (Conacyt) Scholarship for Doctoral Studies in Agricultural Sciences.

\section{REFERENCES}

Adimassu, Z., Alemu, G., and Tamene, L. 2019. Effects of tillage and crop residue management on runoff, soil loss and crop yield in the humid highlands of Ethiopia. Agricultural Systems 168:11-18. https://doi.org/10.1016/j.agsy.2018.10.007.

Ayub, M., Nadeem, M.A., Tanveer, A., and Husnain, A. 2002. Effect of different levels of nitrogen and harvesting times on the growth, yield and quality of sorghum fodder. Asian Journal of Plant Sciences 1:304-307. doi:10.3923/ajps.2002.304.307.

Bakhite, M.A.E., Badawi, G.H., Odindo, A., and Magwaza, L.S. 2019. Assessment of the effects of winter condition on sweet sorghum yield and sugar content. Turkish Journal of Agriculture-Food Science and Technology 7:166-172. https://doi.org/10.24925/turjaf.v7i2.166-172.1888.

Biberdzic, M., Barac, S., Lalevic, D., Djikic, A., Prodanovic, D., and Rajicic, V. 2020. Influence of soil tillage system on soil compaction and winter wheat yield. Chilean Journal of Agricultural Research 80:80-89. http://dx.doi.org/10.4067/S0718-58392020000100080.

Bihmidine, S., Baker, R.F., Hoffner, C., and Braun, D.M. 2015. Sucrose accumulation in sweet sorghum stems occurs by apoplasmic phloem unloading and does not involve differential sucrose transporter expression. BMC Plant Biology 15:186. https://doi.org/10.1186/s12870-015-0572-8.

Bunphan, D., Jaisil, P., Sanitchon, J., Knoll, J.E., and Anderson, W.F. 2015. Estimation methods and parameter assessment for ethanol yields from total soluble solids of sweet sorghum. Industrial Crops and Products 63:349356. https://doi.org/10.1016/j.indcrop.2014.10.007.

Cole, M.R., Eggleston, G., Petrie, E., Uchimiya, S.M., and Dalley, C. 2017. Cultivar and maturity effects on the quality attributes and ethanol potential of sweet sorghum. Biomass and Bioenergy 96:183-192.https://doi.org/10.1016/j.biombioe.2016.12.001.

da Silva, T.M., de Oliveira, A.B., de Moura, J.G., da Trindade Lessa, B.F., and de Oliveira, L.S.B. 2019. Potential of sweet sorghum juice as a source of ethanol for semi-arid regions: Cultivars and spacing arrangement effects. Sugar Tech 21:145152. https://doi.org/10.1007/s12355-018-0637-8.

Fan, Y., Miguez-Macho, G., Jobbágy, E.G., Jackson, R.B., and Otero-Casal, C. 2017. Hydrologic regulation of plant rooting depth. Proceedings of the National Academy of Sciences of the United States of America 114:10572-10577. https://doi.org/10.1073/pnas.1712381114.

Gomez, F.E., Muliana, A.H., Niklas, K.J., and Rooney, W.L. 2017. Identifying morphological and mechanical traits associated with stem lodging in bioenergy sorghum (Sorghum bicolor). BioEnergy Research 10:635-647. https://doi.org/10.1007/s12155-017-9826-7.

Gutjahr, S., Clément-Vidal, A., Soutiras, A., Sonderegger, N., Braconnier, S., Dingkuhn, M., et al. 2013. Grain, sugar and biomass accumulation in photoperiod-sensitive sorghums. II. Biochemical processes at internode level and interaction with phenology. Functional Plant Biology 40:355-368. http://dx.doi.org/10.1071/FP12177. 
Kumar, C.G., Fatima, A., Rao, P.S., Reddy, B.V., Rathore, A., Rao, R.N., et al. 2010. Characterization of improved sweet sorghum genotypes for biochemical parameters, sugar yield and its attributes at different phenological stages. Sugar Tech 12:322-328. https://doi.org/10.1007/s12355-010-0045-1.

Liu, Q., Ma, H., Lin, X., Zhou, X., and Zhao, Q. 2019. Effects of different types of fertilizers application on rice grain quality. Chilean Journal of Agricultural Research 79:202-209. http://dx.doi.org/10.4067/S0718-58392019000200202.

Mangena, P., Shimelis, H., and Laing, M. 2018. Characterisation of sweet stem sorghum genotypes for bio-ethanol production. Acta Agriculturae Scandinavica, Section B-Soil \& Plant Science 68:323-333. https://doi.org/10.1080/09064710.2017.1400586.

Maw, M.J., Houx III, J.H., and Fritschi, F.B. 2016. Sweet sorghum ethanol yield component response to nitrogen fertilization. Industrial Crops and Products 84:43-49. https://doi.org/10.1016/j.indcrop.2016.01.038.

Mekdad, A., and Emam, S. 2019. Biofuel, sugar content, grain yields and qualities of two Sorghum bicolor in responses to levels and timing of nitrogen applications. Egyptian Journal of Agronomy 41:105-117. doi:10.21608/agro.2019.10075.1152.

Miyashima, S., Sebastian, J., Lee, J.Y., and Helariutta, Y. 2013. Stem cell function during plant vascular development. EMBO Journal 32:178-193. https://doi.org/10.1038/emboj.2012.301.

Morey, S.R., Hashida, Y., Ohsugi, R., Yamagishi, J., and Aoki, N. 2018. Evaluation of performance of sorghum varieties grown in Tokyo for sugar accumulation and its correlation with vacuolar invertase genes SbInv1 and SbInv2. Plant Production Science 21:328-338. https://doi.org/10.1080/1343943X.2018.1510737.

Olugbemi, O., Aboyeji, C., Olofintoye, J., and Eifediyi, E. 2018. Growth and ethanol yield responses of sweet sorghum [Sorghum bicolor (L.) Moench] varieties to nitrogen fertilizer rates. Journal of Agricultural Sciences-Sri Lanka 13:114. doi:10.4038/jas.v13i1.8296.

Oyier, M.O., Owuoche, J.O., Oyoo, M.E., Cheruiyot, E., Mulianga, B., and Rono, J. 2017. Effect of harvesting stage on sweet sorghum (Sorghum bicolor L.) genotypes in western Kenya. Scientific World Journal 2017:1-10. https://doi.org/10.1155/2017/8249532.

Pannacci, E., and Bartolini, S. 2016. Evaluation of sorghum hybrids for biomass production in central Italy. Biomass and Bioenergy 88:135-141. https://doi.org/10.1016/j.biombioe.2016.03.024.

Pittelkow, C.M., Linquist, B.A., Lundy, M.E., Liang, X., van Groenigen, K.J., Lee, J., et al. 2015. When does no-till yield more? A global meta-analysis. Field Crops Research 183:156-168. https://doi.org/10.1016/j.fcr.2015.07.020.

Rolz, C., de León, R., de Montenegro, A.L.M., Porras, V., and Cifuentes, R. 2017. A multiple harvest cultivation strategy for ethanol production from sweet sorghum throughout the year in tropical ecosystems. Renewable Energy 106:103-110. https://doi.org/10.1016/j.renene.2016.12.036.

Rono, J.K., Cheruiyot, E.K., Othira, J.O., and Njuguna, V.W. 2018. Cane yield and juice volume determine ethanol yield in sweet sorghum (Sorghum bicolor L. Moench). International Journal of Applied Science 1:29-29. https://doi.org/10.30560/ijas.v1n2p29.

Schneider, F., Don, A., Hennings, I., Schmittmann, O., and Seidel, S.J. 2017. The effect of deep tillage on crop yield-What do we really know? Soil and Tillage Research 174:193-204. https://doi.org/10.1016/j.still.2017.07.005.

Shukla, S., Felderhoff, T.J., Saballos, A., and Vermerris, W. 2017. The relationship between plant height and sugar accumulation in the stems of sweet sorghum (Sorghum bicolor (L.) Moench). Field Crops Research 203:181191. https://doi.org/10.1016/j.fcr.2016.12.004.

Soil Survey Staff. 1999. Soil taxonomy: a basic system of soil classifica-tion for making and interpreting soil surveys. $2^{\text {nd }}$ ed. United States Department of Agriculture, Natural Resources Conservation Service, Washington, DC, USA.

Tang, C., Sun, C., Du, F., Chen, F., Ameen, A., Fu, T., et al. 2018. Effect of plant density on sweet and biomass sorghum production on semiarid marginal land. Sugar Tech 20:312-322. https://doi.org/10.1007/s12355-017-0553-3.

Tovignan, T.K., Fonceka, D., Ndoye, I., Cisse, N., and Luquet, D. 2016. The sowing date and post-flowering water status affect the sugar and grain production of photoperiodic, sweet sorghum through the regulation of sink size and leaf area dynamics. Field Crops Research 192:67-77. https://doi.org/10.1016/j.fcr.2016.04.015.

Tsuchihashi, N., and Goto, Y. 2005. Internode characteristics of sweet sorghum (Sorghum bicolor (L.) Moench) during dry and rainy seasons in Indonesia. Plant Production Science 8:601-607. https://doi.org/10.1626/pps.8.601.

Vanderlip, R.L. 1993. How a sorghum plant develops. Contribution N¹203. Kansas Agricultural Experiment Station, Manhattan, Kansas, USA.

Vermerris, W., and Saballos, A. 2013. Genetic enhancement of sorghum for biomass utilization. p. 391-425. In Paterson A. (ed.) Genomics of the Saccharinae. Springer, New York, New York, USA.

Zhai, Z., Li, Y.Y., Zhang, L., Pang, B., Pang, H.C., Wei, B.H., et al. 2017. Effects of short-term deep vertically rotary tillage on topsoil structure of lime concretion black soil and wheat growth in Huang-Huai-Hai Plain, China. Journal of Applied Ecology 28:1211-1218. doi:10.13287/j.1001-9332.201704.016.

Zhang, F., Wang, Y., Yu, H., Zhu, K., Zhang, Z., and Zou, F.L.J. 2016. Effect of excessive soil moisture stress on sweet sorghum: physiological changes and productivity. Pakistan Journal of Botany 48:1-9. https://www.pakbs.org/pjbot/PDFs/48(1)/01.pdf.

Zhao, Y.L., Dolat, A., Steinberger, Y., Wang, X., Osman, A., and Xie, G.H. 2009. Biomass yield and changes in chemical composition of sweet sorghum cultivars grown for biofuel. Field Crops Research 111:55-64. https://doi.org/10.1016/j.fcr.2008.10.006. 